International Journal of Social Sciences and Humanities
Available online at http://sciencescholar.us/journal/index.php/ijssh
Vol. 3 No. 1, April 2019, pages: 193 202
e-ISSN: 2550-7001, p-ISSN: 2550-701X
https://doi.org/10.29332/ijssh.v3n1.335

\title{
Social Rights on Hindu Religion and Untouchability towards Politics and Law
}

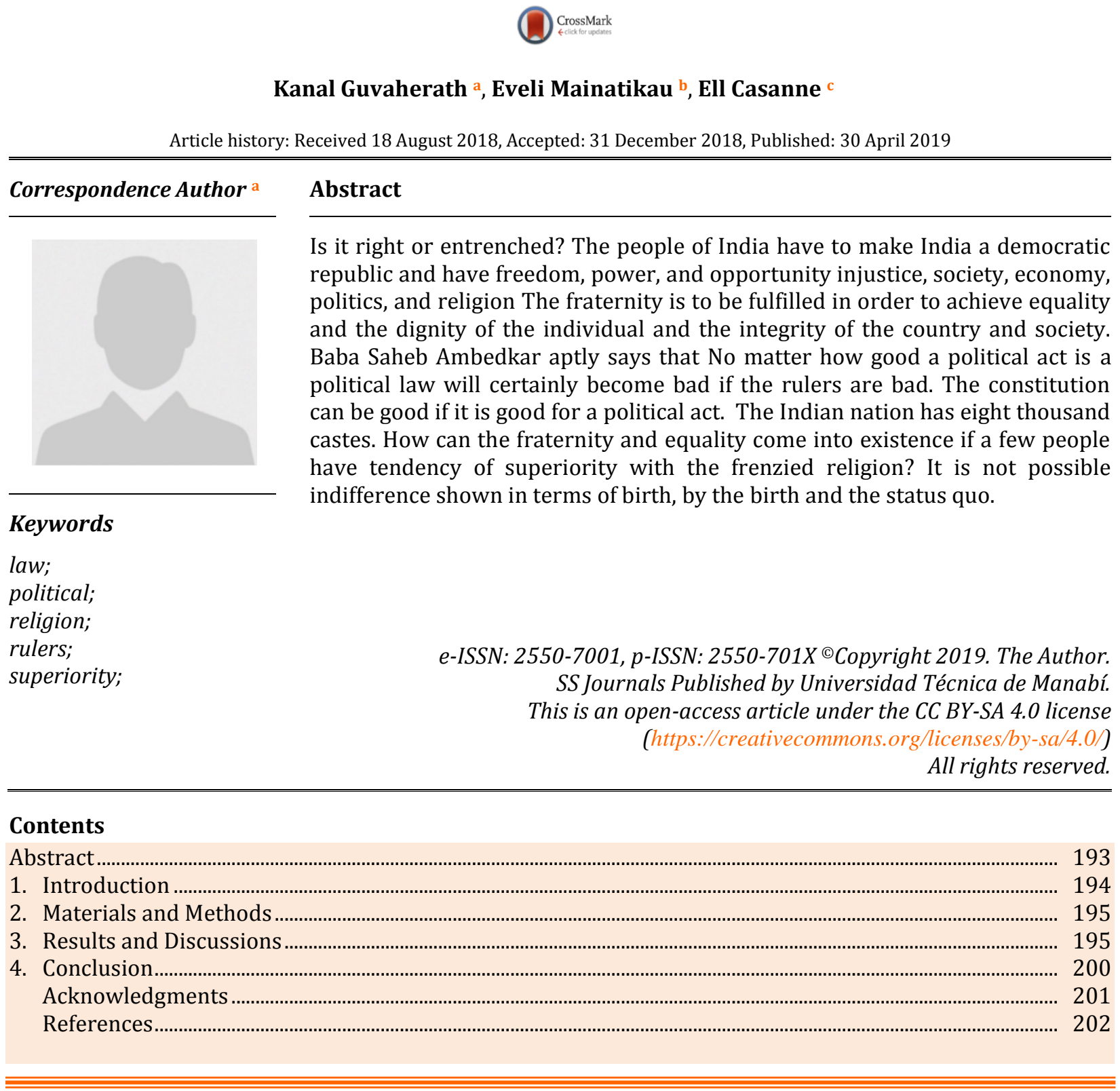

\footnotetext{
a Wayamba University of Sri Lanka, Kuliyapitiya, Sri Lanka [Email: guvaherath.k@wyb.ac.lk]

b The University of Fiji, Lautoka, Fiji

c Université Cadi Ayyad, Marrakesh-Safi, Morocco
} 


\section{Introduction}

The earliest belief altered i.e. the idea that the people were created by God was changed due to the emergence of science and technology. Growing up gradually from the Neolithic race to evolutionary state is the history of human evolution. These are the reasons for their life and development. Historians who refuse to believe that all these developments are fundamental to all developments. The purpose of this research is to examine the social rights from this perspective. Community is a group of people with a number of individuals. Many communities collectively considered as a community. Tamil community is alive and active with many communities. The social stratification, which is divided into multiple categories based on the qualification level, is called a social order system. Sociologists' says that social organization is an organization in which people are shared significantly in both the property and the inner self. Society and community are both refer as a group of people. Group of people like Brahmin community had been raised as an individual community, as well as Scheduled Tribal communities. These communities are split up into many castes. Roughly it was estimated between 3,000 and 8,000 thousand castes. "There are three types of people who suffer in their lives. They are the mountain tribes, tribe people (aborigines), and backward classes. Tribal people and economically weak people fall under the atrocities of untouchability." (Anbuponnoviyam,149). It is a crime against their social rights, implemented by the caste divisions. Tribal tribes and tribal people suffered through slavery and suffer from horrors. They are untouchable and slaughtered by politics. These are the consequences of social rights denial. The indigenous people are unique. However people of low caste and class suffer from the suppression, oppression, domination, and cruelties (Lijphart, 1996; Audretsch et al., 2013).

\section{Literature Review}

According to Dr.Ambedkar today's reserved population of Dalit people has been reduced to about 400 years ago by human society and undermined by untouchability". "According to historian Srinivasa Iyengar, the name of the Adi Dravida was not seen in history before 800 years". But the history of the allotted schedule caste people like the slaves can only be found in our Indian history (Singh, 2011; Haynes, 2008).

Anbuponnoviyam opines, thus the Dalit people have been downgraded because of the inadequacy of inequality, ignorance, poverty, illiteracy, looking dirty, the inferiority complex that's why analyzing the mainstream history of India and the present political leaders registered history through their speeches and writings.

Imayam's says in his article fashion history tells, "The human society that has taken a civilized life from barbarism and it's created a lot of literature with rigorous growth, but it shows a mature maturity? In this development, the Dalit people have a great deal of flexibility."

Thomas in Hindu Religion and Manners says that the peasant community was entirely farmers after that they converted to several jobs. Those who involved in the agriculture after getting blessing they became Brahmin; Those who involved in the war after getting the victory they became Chathriyaas; Due to business few people became a Vaishyas; due to agriculture few people became laborers; this difference is just indicated their position, not the birthplace. By profession, it is noteworthy that today's wealthy people are the fourth class those who are involved in the labors are coming under the fifth class.

According to J.H. Hutton, during the prehistoric period, the people of Southern India spread across the Ganga plains and built a number of towns and cities. A new policy storm began to evacuate among the survivors. This policy was adopted by fear and dignity. It swallowed across North India and attacked Tamil Nadu. Tamil people like "Ariyar" welcomed that policy. In the end, the policy became a racial upheaval.

The article, M.C.Rajah's oppressed Hindu says that Petra's dominance over the Indus River stretched across the river Ganges slowly. At that time, some began to oppose the new civilization. The unwelcome started to be a mixed Dravidian. They were subjected to neglected Dravidian. The majority of people are welcome the new innovation, and the minority is opposed to it. Most were reserved for minority slaves and untouchables they had lived outside of the village.

Edger Thurston, cast and tribes of southern India, says, in olden times when the rule of monarchy, uppercaste people got a thousand acres of land, others gaining the level of farming lands, and others got employed in the government's jobs and they uplifted their positions. People of today's tribal Adi Dravidar have fallen down without getting such concessions. The historical truth is they were subordinated. The Poona Agreement 
concludes that Dalit leaders have been entrusted with the right to a large number of necessary rights, such as the concessions received by the upper castes (Mawdsley, 2006; Makki et al., 2015).

V.R. Ramachandra Dikshitar's, War in Ancient India, says people are not created by God. They are growing up gradually from the Neolithic race to evolutionary evolution. These are the reasons for their life and development. Historians who refuse to believe that all these developments are fundamental to all developments. The purpose of this research is to examine "social rights" from this perspective.

According to Irattaimalai Srinivasan, Madras legislative council proceedings says, Anniversary ceremonies held annually by the untouchable are the rituals performed by the untouchables it was conducted by nonuntouchables. These are the result of religion given by the Lord. It was not given by partial devotees. Today's problem is the idea of this religion and the topic of untouchability. Owen M. Lynch, the politics of untouchability says, as a result of India's 150 years under British rule, the so-called upper clan of the Indian community was advancing Western education and culture - and it was not surprising that they were also interested in English rule positions. It needed a movement. It was also set up by an Englishman. It named has Indian National Congress. The leaders of the 1886-1895 conference noted that this movement would only involve politics and not reform or socialize or not. They liked the autonomous system (Ghosh, 2018; Chatterjee, 2005).

\section{Materials and Methods}

According to the researcher perspective, this issue comes under the subaltern theory. Subaltern means it's a military term it refers to the person on whom in the last cadre or rank. Dalit issues and problems struggles fall under this category.

\section{Results and Discussions}

\section{Social development}

The archaeologist not only finds out how a man actually lived in a particular period of time but also examine the emergence of different people like Dalits. The evidence clearly claiming that the above three people are the same ethnic group. People living in early history engaged in hunting and collecting food items as small groups or societies. The society was always a kind of organization because everyone has done the same job in the past. But, social status differences began to emerge at the end of the age. The differences are so close to civilization. The people indulged in the jobs that are made up of the caste-based on the social classes. The archaeological and historical opinion is that the wild population, the indigenous tribes, the indigenous population, and the late people are the people of the aborigines. They can dare to say that they are descendants of the intermediate people. The livestock people are the descendants of the medieval peoples. The benefits of agriculture have been widely acknowledged. The development of agriculture leads to the production of tools that were invented by their joint social life. They could have lived and hunted along with agriculture. Their labor, growth, and efforts in the past became the cause of the country's nativity. They have become victims of time (Rao, 1999; Lodhia, 2015).

"The embankment of a foreign policy i.e. accepting the monarchy invites some changes in their lives. The kings are the first one to minimize the rights of society on land. The kings are observed people as a representative of society" "(Anbuponnoviyam, 150). The king has the right to take possession of the land and house of the peasants. The justice books claim it as rules of Chathriyaas. At the same time, the books also taught the priesthood. As a result of the struggle of the two classes and powers were shared as a leader for religion. The bureaucracy also created two other divisions, Vaishya and Shutra. It was written that the four Varnas were born from the mouth, the shoulder, the thigh, and the foot of the Lord Brahma, the creator. The story as legendary remains unrevised legendary mythology due to the half-hearted priests.

Guvaherath, K., Mainatikau, E., \& Casanne, E. (2019). Social rights on hindu religion and untouchability towards politics and law. International Journal of Social Sciences and Humanities, 3(1), 193-202. 
Social fall

Lifestyles were collected for four Varnas. One of the first two classes became the Chairperson or head and the next priest became the chief advisor to the king. The ruler was forced to rule under the advice of the priest. Many of the books of the jurisdiction were raised. They made kings the highest of the nobles. The Vaishyas were instructed to do all the assistance to the upper classes. The Sutras found the threat and slavery from the other three ethnic groups.

This resulted in the lives of Dalit people, land settled tribes, and other people who lived in the least caste. They engaged in other industries and cultivation works. Temples appeared. Great landlords and farmers addicted to Brahma landlords. The practice to donate the lands along with the inhabitants started in South India. When the villages were donated to the Brahmins, the inhabitants of the village were forced to leave the town and stay there. The rural people were given orders to provide food services to the cluster and the government officials.

The regime was stronger, and religion was much stronger. Politics and religion looted the lives of the people. It seemed to be like a boutique. The birthday of the king celebrated as a ceremony. In that festival gold, materials, cows, and lands were also needed to buy gifts. Taxes were implied on the people to compensate for this. Many lost their wealth and became victims. They have settled in the mountainous areas. Many people have been attaining slavery and the slavery of repression spread throughout the country. The Varnas concept sprouted on the banks of the River Sindu and stretched across the River Ganges. The vast majority of the people agree the concept but the minorities were in a position to oppose it. The majority people were naturally stood against minorities. They slaughtered minorities. Minorities became untouchables. They fell under the clutch and forced to leave and live outside of the village.

\section{Refusal of Social rights}

Many changes created by religion. The concept altered. Religion for people slowly shifted from the people for religion. This change worsens the condition of the Scheduled Tribes because the Tamil kings were given the lands to Brahmins. The people refused religious and Brahmin concepts were subjugated in due course of time they became untouchables. "Srinivasa Iyengar would say that these people who refused to accept the Brahmin principles became untouchables" (Anbuponnoviyam, 153). There is a tradition arose in which the Scheduled Tribes are addressed as Panchamas. The upper class said that these people were the Buddhists and were untouchables. The untouchability based on religious origin dragged and dropped on the basis of birth. "As a result the Scheduled class tribes are restricted to walk on public roads, to take water in any of the wells or tanks, to use good vessels, to eat good food and to worship Hindu Gods" (Anbuponnoviyam, 153). There were so many restrictions on it. Apart from the Brahmins, non-Brahmin caste Hindus also started to suppress the Scheduled masses. This oppression exists from the past, continues even in the ruling of invaders and even after the arrival of the British people. The oppression was projected as a part of the religious laws of the majority. Thus the Tamil caste fanatics are in the stranger regime. Caste schemes have been adopted by the name of the religion to the setup class on the terms of the law.

\section{Social rights and desire}

The ancient Tamil Nadu it was said that the system was centered in one place and the powers were spread around. The people enjoyed the sovereignty in the society and the social work of the people was centered on the temples. The temples are in the middle of the villages. The temples would be surrounded by people. The temples had the judiciary courts i.e. Panchayath. Those courts gave justice and maintain harmony. But it is not true entirely. Temple also contradicted the people. Religion is the main reason for the barbarous behavior against Dalit people and Scheduled Class tribes. They cannot be recovered from this crisis. "Those who lost their lives could not understand and progress in a righteous way. They are dragged away from the progress by the upper caste people" (Anbuponnoviyam, 155). "Most people do not realize that society can massively overpower the brutality and repression of the individual than the government. The repressive system of society is even more powerful than the government" (Anbuponnoviyam, 156). "The law can guarantee a variety of rights. But the rights which are executed in the community can be called real rights. If the rights of 
the law are opposed by society, then the rights do not have any effect" (Anbuponnoviyam, 156). Schedule classes require more social rights than the rights guaranteed by law. Until such social rights are not available, the right of law does not make any sense. 'Baba Saheb Ambedkar strongly registers those rights which have to be considered. A set between the slave and slavery is assigned to the people of Dalit community" (Anbuponnoviyam, 156). This dishonesty is inconvenient to interfere with others, and they are denied the right to be in public life and are denied the right to enjoy all living opportunities." Sixty years ago Ambedkar pointed the terrible situation where horrors, brutal regulations, and injustices happen in the autonomous state" (Anbuponnoviyam, 156). Slavery does not change until the lifestyle scheduled tribe change. The only thing that can be distinguished in that the Dalit people can get rid of their social hardship.

\section{Hindu Religion and Untouchability}

Anniversary ceremonies are held annually by the untouchables, performed by the untouchables and for the non- untouchables. These are the result of religion. It was not given by the learned peoples. The idea of this religion and the topic of untouchability will be analyzed in Ambedkar's perspective. Untouchability and its origin should be researched. Hundreds of Hindus are considered as untouchables by the Hindus. The list of Indian government's law in 1935 is a surprising list. It consists of four hundred and twenty-nine classes as untouchables. There is about five crores to six crores are considered as untouchables. This untouchability system cannot be found in practice of ancient and other non-Hindu societies. It is regrettable that the history of India does not shake the process this phenomenon. "The struggle between Buddhism and Brahmins to dominates the untouchability of around $400 \mathrm{BC}$. Initially, only twelve classes had been fall under untouchability after its spread to 429 classes. The fact about the spreading has to be re-searched" (Anbuponnoviyam, 29).

Everyone in India is addressed as Hindus. In this sense, there is no doubt that untouchables can be called as Hindus. But the same criterion can be applicable to Muslims, Christians, Sikhs, Jews, and Parsis. Secondly, the term 'Hindu' is also used in religious terms. in this regard, it is necessary to separate the mythical and ideologies of Hinduism separately from the worship traditions of Hinduism and reactions. Those who are untouchables in the religious sense are Hindus, what they choose depends on ideology or religious traditions decides their identity. The fundamentals of the Hindu faith are caste and untouchability; each untouchable will make the Hindu religion and the one who is a Hindu in a definite and resolute decision. A considered part of a Hindu society addressed as untouchables. The humanitarian bond that connects them with other sections of the Hindus is meek and fragile. The Hindus and the Untouchables follow their worship tradition in a different way, although their worship traditions are similar yet kept as strange things.

\section{Religious discrimination}

There is a nice argument in Hindu religion towards untouchability as religious discrimination or discrimination within a religion. The argument should be accepted that the untouchable Hindus are Hindus. Like other Hindus, the untouchables worship the same deities and angels. The same phenomenon has beliefs. The untouchables and the Hindus are the backbones of the same religious community. Instead of Hindu unity, it teaches separation. The caste system and untouchability hold up discrimination. From the Dalit perspective the true nature of Hinduism is to divide people because it clearly indicates division and dispatchers. Caste is another name for division. Untouchability refers to a larger form that separates a community from another community. In fact the Hindus and the Untouchables are separated by a pendulum by pin wires. The same Hindus who do not touch the Hindus are Hindus do not accept the Untouchables as an inseparable part of Hindus but have always insisted on the principle and the practice that they should be separated from the Hindus and to be treated as a separate section.

\section{Social problem or political problem?}

The problem of the untouchables is a social problem. Today the majorities refuse to give equal opportunity and freedom to minorities. They are plotting to impose their policy on the minorities. The problem with the face of untouchability is to make the majority of the people who have such hostility to freedom and equality

Guvaherath, K., Mainatikau, E., \& Casanne, E. (2019). Social rights on hindu religion and untouchability towards politics and law. International Journal of Social Sciences and Humanities, 3(1), 193-202. https://doi.org/10.29332/ijssh.v3n1.335 
for the minorities. From this point of view, it is clear that the untouchability issue is a political issue underlying. In fact, the state is one of many organizations of society. The community refers to the government to do some of the obligations needed for the collective life of society.

\section{Religious order}

To revolutionize the anti-social fabric of the untouchables is a wise way. The Hindu religion is sacrilegious because it is divine. It is not only sacred but also restriction is prescribed in all possible ways. If the society does not listen to the voice of the untouchables it is not humanity. Hinduism is the commandment that they should not be considered as human beings. Beating the Untouchables, plundering of their property, burning them, and placing them with various atrocities, Hinduism teaches that they do not commit any sin to point to this social file. There is nothing to be hoped for by the Hindu subordinates. This is not the only reason why depressed people want to go out of Hindu principles. Some people may think that the details presented here are about the established system and its rules but, the fact that the installed system is still in existence today. It is still functioning today as it is under its rules. There are certain disadvantages are faced by Dalits in society.

\section{The first census}

According to the first census in 1911 there is a ten concept allotted to differentiate the untouchables from the mainstream society. Based on these norms they conducted the censuses.

1) Those who deny the Brahmins are superior.

2) Those who have not accepted teaching, or chanting mantras from Brahmin group or other allotted groups.

3) Those who are not accepting the Vedas and refusing the power center.

4) Those who are not acceptable to worship great Hindu Gods.

5) Those who are not accepted to the Brahmin's service.

6) Those who don't have contact with Brahmin priest.

7) Those who are not allowed in the ordinary Hindu temples.

8) Those who are not considered as pure.

9) Those who buried dead bodies.

10) Beef consumers and those who do not consider cow as sacred animal.

"Most unfortunate people are suppressed, people. When the minority comes into the affairs the upper caste created a new oppressive philosophy of Hindi nationality. On the part of the Hindu community, on a society that is less favorable, If one can express this kind of blatant blatantly, then nothing can be expected from the Hindus who think that the Manu dharma is best" (Anbuponnoviyam, 34). "Dr. Ambedkar asks a question and explains the life of the untouchable. The Untouchables are outside from the Hindu community, but a question arises. How far were they from the Hindus? Even if they are not Hindus, how much do Hindus respect or sympathize with human beings? Without answering these questions, one cannot find complete ideology about the life of the Untouchables" (Anbuponnoviyam, 34). The first example comes from the state of Chennai region. In 1909 people filled a petition in the high court. Both the petitioners and accused are caste Hindus. The petitioner "Subbareddy wants to block a group who are in Campaign. He decided that the perfect way was to bring some of the untouchables and make them stand on the road" (Anbuponnoviyam, 34). The campaign of upper caste was stopped and dropped the protest as the caste Hindus feared about purity. The Madras High Court passed the judgment that the hawking on the road was not a hindrance. The Paraiyas existence is enough to control the campaign of the caste Hindus. What does this mean? This means that the Hindus have a total disgrace upon the untouchables. 
A hundred year's crisis

According to the Government Order of 1993, the Scheduled caste was hoe they treated, in the 1930s, the first Dalit freedom fighter of the Madras Legislative Council, Irattaimalai Srinivasan, said the following issues as a hundred years crisis of Dalits:

1) Bring out the criminal cases about the Dalit people in village Panchayath and justice courts.

2) The barren lands around the Paraiyas lands were occupied by raising a petition to the government. Denied grazing of Paraiyas cattle in those lands and the banning of the way they go to the temple.

3) Write down the name of the Miras in fraudulent state account against the Paraiyas.

4) Disallow residence of housing in the lower castes.

5) Deny the right to a fund-collecting method that has been in existence for a long time.

6) Filing case against those who involving harvesting in the Paraiyas land.

7) Cheat and take the signature in the bonds (agreement copy) of the characters and then make them hydrated.

8) Diverting the water flowing to the Scheduled Castes land.

9) Without a statutory foreclosure, claim the lease amount or instead forced to sign in the selling document.

Between 1893 and 1930, the situation of Dalit ethnic groups did not change. From 1900 to 1920, governments ruled under governor's rule under the British Governor-General (Viceroy). In Tamilnadu, from 1920 to 1926, the Justice Party and the non-Party private cabinet regimes from 1926 to 1937 have existed. In this period also there is no decrease in the atrocities against Scheduled Tribes, but rather they increase. M. C. Raja in Tanjore conference stated that from 1893 to 1945 in British rule the atrocities against Dalits never decrease. It is considerable statement. He further claims that "From the time of the rule of the Tamil kings, the AdiDravida was treated very cruelly. The academic status of the Adi Dravidians and the economic status of the Adi Dravidians are quite erratic since the British began to rule India for over a hundred years." He has shown the above message in his book elaborates and explains the horrible social law that is happening in Indian villages against Dalits.

1) The Untouchables should live in separate areas beyond the habitat of the Hindus. The violation of the dividing rule is a crime.

2) The area of the untouchables should be in the south direction because the south is considered as much unsuspicious in four directions. Violation of this rule is considered as a crime.

3) The untouchables should follow the fate of the distance or the shadow of the unclean. The violation of this rule is a crime.

4) People from untouchables should not build a house in tiles.

5) Dalit People dressed in pure clothes dress up the shoe, wearing a watch and gold jewelry is also a crime.

6) Members of the unscrupulous community are accused of adding wealth, such as land and domestic animals.

7) The Untouchables should not name their children with majestic sounds. Their names must be a sign of contempt.

8) The Untouchables is accused of sitting on a chair before the upper-caste Hindus.

9) The untouchables are not allowed to travel above the horse and using chariot is also a crime.

10) The Untouchables are guilty of rallying through the village.

11) If Untouchables are not greeting the upper caste Hindus it is also a crime.

12) The untouchables should not speak the dignified language.

13) The Untouchable Hindus during the celebrations and fasting days will not enter into the village and walk on the streets of upper caste people. Their breath and air considered to be the pollution and impurity by the caste Hindus.

14) The untouchables are not allowed to be like an ordinary person. If they project like that it will be a crime.

15) The untouchables have to maintain lowly position, Dalits must have the following external icons to recognize them. They should have undignified name and unclean clothes.

16) Dalits have to carry news to the other villages about marriage and death of caste Hindus.

17) At the upper caste, Hindu marriages Dalit has to do the menial works.

Guvaherath, K., Mainatikau, E., \& Casanne, E. (2019). Social rights on hindu religion and untouchability towards politics and law. International Journal of Social Sciences and Humanities, 3(1), 193-202. https://doi.org/10.29332/ijssh.v3n1.335 
18) The upper caste women after the child birth while going back to his native a dalit person has to accompany.

19) Dalit has to serve all the work required in the public ceremony to celebrate rural community festivals.

20) Dalits have to allow some of the dishonest to their women in public festivals.

\section{Untouchability and pride}

Ambedkar, who generally speaks of events, shows evidence of the unwritten social laws in certain circles. In 1927, the Indore district comprised of 15 caste Hindus like Rajputras, Patels, Patrvaries, and the Brahmins listed things of conduct to Dalits. If they violate they are not allowed to live in their villages. Ambedkar also pointed out that the cruelties have been shown in British India, ruling of Zamin and landlords. "The Mewar Harijan Service Union has submitted a petition to the state government in 1945 on the livelihoods of Harijans in Mewar. According to the petition, the civil rights of the Harijans are affected by the caste Hindus pride and discrimination." (Anbuponnoviyam, 2014) says Ambedkar. Every caste Hindu in the village thinks that he is superior to the untouchables. None of the atrocities against Dalits has been placed in the penal code enacted by the British government. These are actual crimes, in the case of Untouchables. Untouchability can be a curse for the untouchables, but it is undoubtedly a boon for Hindus. It gives a class to the Hindus to consider themselves inferior to themselves. Hindus prefer a system that is important to them and others. The Untouchables are not important. It makes Hindus important. The practice of untouchability makes the Hindu a natural pride, helping them to think and show them as bigger. This is the reason why the Hindus, especially the small majority of the population, have no chance of abandoning the untouchability. Unlike the caste system, especially the caste system, the untouchability can be disappeared. Unfortunately, when India's minority comes into the affair, the growing masses of the people will be able to subdue the Dalits through the Indian nationalism with a new oppressive ideology. If the Sutras wanted to Brahmins down, the untouchables did not want to rise to their position. They want to withstand the insults that the Brahmins carry on those who do not have the same steps on the social system along with the untouchable. As a result, there is no one to join them in the struggle of the untouchables. They are totally isolated. Besides being isolated, classes that are naturally friendly for them are opposed to them. Thus loneliness is a hindrance to the abolition of untouchability.

Sutras are showing hatred towards those who do not touch more than the hatred of the Brahmins. In fact, those who do not touch on the Hindu social system are those who act as a police force to break the touch of attack. This is a strange situation, but true. The rights of citizens can not mean the rights of untouchables. For the people, the people's government is not the government for the untouchables. Everyone's equal opportunity does not mean equal rights to the untouchables. All untouchables encounter discrimination across the country and face a scarecrow. India is the nation with most oppressed people who are being given injustice everywhere. It's a big truth and the untouchables who experience all these sufferings. Law is useless. Do Hinduism theory recognizing those deemed as human beings? Is it stands for their equality? Will they give them the benefit of freedom? Will it try to build a fraternal frenzy between the lowest of the lower castes and the Hindus? Should Hinduism say to the Hindus that they should be treated with dignity, fairness, and humanitarianism? No Hindu can answer such questions. They filled with consciousness and tradition of the general public. The Hindus and the deprived people cannot be bound by law. They cannot unite with any electoral law. They have only one thing to bond, that's love.

There should be a policy to prevent social injustice like, no man should be interrupted, no religion should be destroyed, everyone should live and live let the others live are the seeking right. One does not need to get a right to birth but, need right to die. All are born free when they are born. As you grow up in the Middle Ages, many comments are being put on them. In some way, they have to accept them.

\section{Conclusion}

The nomad barbaric life is far better than the contemporary indifferent republic life. Barbaric life in which people lived with freedom and rights but in the contemporary civilian life follows the immortal slavery in practice. Today's people who are said to be civilians can be said to be silly with the caste indifference and 
untouchability. The fact that the world knows is that it in Indian nation indifference is thereby showing the birth, showing God, showing religion and hold Dalit people brutally. Is it right or entrenched? The people of India have to make India a democratic republic and have freedom, power, and opportunity injustice, society, economy, politics, and religion The fraternity is to be fulfilled in order to achieve equality and the dignity of the individual and the integrity of the country and society. Baba Saheb Ambedkar aptly says that No matter how good a political act is a political law will certainly become bad if the rulers are bad. The constitution can be good if it is good for a political act. The Indian nation has eight thousand castes. How can the fraternity and equality come into existence if a few people have tendency of superiority with the frenzied religion? It is not possible indifference shown in terms of birth, by the birth and the status quo.

Limitation and Study Forward

This study focusses only about the Dalit issue further it will be carried out problems of women's tribes and disables.

\section{Acknowledgments}

The author would like to acknowledge the editor and reviewer of IJSSH for their valuable time, support, and advice in completing the current research.

Guvaherath, K., Mainatikau, E., \& Casanne, E. (2019). Social rights on hindu religion and untouchability towards politics and law. International Journal of Social Sciences and Humanities, 3(1), 193-202. 


\section{References}

Singh, P. (2011). We-ness and welfare: A longitudinal analysis of social development in Kerala, India. World Development, 39(2), 282-293. https://doi.org/10.1016/j.worlddev.2009.11.025

Haynes, J. (2008). Religion and foreign policy making in the USA, India and Iran: towards a research agenda. Third World Quarterly, 29(1), 143-165. https://doi.org/10.1080/01436590701739668

Lijphart, A. (1996). The puzzle of Indian democracy: A consociational interpretation. American political science review, 90(2), 258-268. https://doi.org/10.2307/2082883

Audretsch, D. B., Boente, W., \& Tamvada, J. P. (2013). Religion, social class, and entrepreneurial choice. Journal of Business Venturing, 28(6), 774-789. https://doi.org/10.1016/j.jbusvent.2013.06.002

Mawdsley, E. (2006). Hindu nationalism, neo-traditionalism and environmental discourses in India. Geoforum, 37(3), 380-390. https://doi.org/10.1016/j.geoforum.2005.06.004

Makki, M., Ali, S. H., \& Van Vuuren, K. (2015). 'Religious identity and coal development in Pakistan': Ecology, land rights and the politics of exclusion. The Extractive Industries and Society,2(2), 276-286. https://doi.org/10.1016/j.exis.2015.02.002

Ghosh, P. S. (2018). The politics of personal law in South Asia: Identity, nationalism and the uniform civil code. Routledge India. https://doi.org/10.4324/9780429506826

Chatterjee, P. (2005). The nation in heterogeneous time. Futures, 37(9), 925-942. https://doi.org/10.1016/j.futures.2005.01.011

Rao, S. (1999, May). Woman-as-symbol: The intersections of identity politics, gender, and Indian nationalism. In Women's Studies International Forum (Vol. 22, No. 3, pp. 317-328). Pergamon. https://doi.org/10.1016/S0277-5395(99)00033-3

Lodhia, S. (2015, May). From "living corpse" to India's daughter: Exploring the social, political and legal landscape of the 2012 Delhi gang rape. In Women's Studies International Forum (Vol. 50, pp. 89-101). Pergamon. https://doi.org/10.1016/j.wsif.2015.03.007 